\title{
Design, Fabrication, and Standardization of Visual Perception Error Measurement Test (Understanding the Size of the Length)
}

\author{
Akbar Malekahmadi $^{1 *}$, Mehdi Rozbahani ${ }^{1}$, Hamidreza Hekmat ${ }^{1}$, Masoud Sadeghi \\ 1 Dept of Psychology, Borujerd Branch, Islamic Azad University, Borujerd, Iran \\ 2 Dept of Psychology, Lorestan University, Khorramabad, Iran
}

Article Info A B S T R A C T

Article type:

Research article

Article History:

Received: 06 February 2021

Revised: 21 February 2021

Accepted: 16 October 2021

\author{
* Correspondence to: \\ Akbar Malekahmadi \\ Dept of Psychology, Borujerd \\ Branch, Islamic Azad University, \\ Borujerd, Iran \\ Email: \\ Akbar_malel2002@yahoo.com
}

Introduction: Visual perception error (VPE), especially in the measurement of physical quantities, is the most important aspect of perception error that has a significant impact on the dimensions of human life. This study aimed to design, fabricate, and standardize the visual perception error test (VPEMT) based on the domains of its distribution in Iranian society, in order to compare different individuals and groups in terms of their scores and means in this domain.

Material \& Methods: This descriptive-survey study was conducted using a number of cards with a two-part image of unequal lines, except for one case as a criterion, and was designed in (T) shape and tested on individuals. Finally, VPEMT consisted of 14 cards (Ta, Tb...Tn) with a difference of half a centimeter in the vertical line. A three-choice question was answered and implemented on 90 people of both genders (16-65 years), and the result was considered the base of the study. The statistical population included 1545-year cases (mean age: 26 years) who lived in Ilam for 9 months. Eventually, a sample of 900 cases of both genders was randomly selected using the block-cluster sampling method and tested with VPEMT.

(Ethic code: 1398.041.CER.B.UAI.RI)

Findings: The validity and reliability of the VPEMT were estimated by halving, within and between experts, and repeated tests ( $r=0.92$ to $r=0.98$; and $\mathrm{r}=0.97$, respectively). VPE has an almost normal distribution (mean $=7.97$, median $=8$, mode $=9$, dispersion $=9$, and range between 3 and 12) and diagnostic cut $(\mathrm{Td} / 10)$ at $80 \%$ level, as well as the minimum and maximum error (1.5-6) $\mathrm{cm}$ in every 12 centimeters. Estimation of standard error showed the confidence intervals of the mean of the population from the mean of the group at the level of $0.05(40 \pm 1 \mathrm{~mm})(41>\mu>39)$.

Discussion \& Conclusion: Based on the research findings, it can be concluded that VPEMT, in showing the amount of VPE, in the population aged 15-45 years, based on two criteria (mean and reality) had very high validity and reliability. It can also be used diagnostically-selectively in different groups in this age range and research. Moreover, it has the potential to be upgraded to an accurate and automated electronic system or software for this purpose in such a way that the subject receives the amount of his/her perception error by pressing the desired key.

Keywords: Criterion, Perception, Visual perception, Visual perception error and test (VPEMT)

\section{\& How to cite this paper}

Malekahmadi A, Rozbahani M, Hekmat H, Sadeghi M. Design, Fabrication, and Standardization of Visual Perception Error Measurement Test (Understanding the Size of the Length). Journal of Ilam University of Medical Sciences. 2021;29(5): 102-116. 


\title{
طراحى ، ساخت و هنجاريابى آزمون سنجش خطاى ادراك بصرى (درى اندازه طول)
}

\author{
اكبر ملك احمدى '* iD ، مهدى روزبهانى'، حميد رضا حكمت'، مسعود صادقى '
}

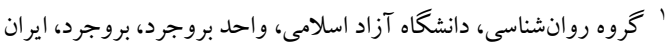

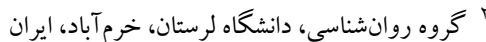

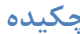
اطلاعات مقاله

مقدمه: خطاى ادراكك بينايى (VPE)، بهويزه در اندازهيرى كميتهاى فيزيكى، مهمترين جنبة خطاى ادراك است كه

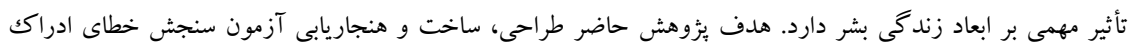

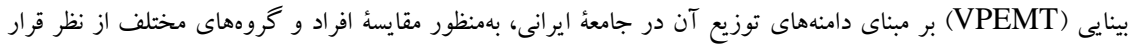
كر فتن نمره و ميانخين هاى آنان در اين دامنه است.

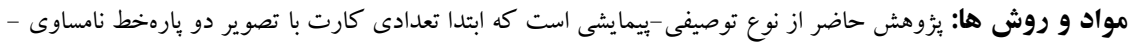

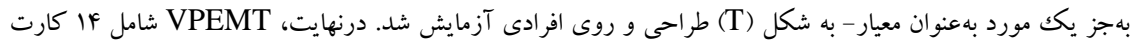
(Ta, Tb, ...Tn)”

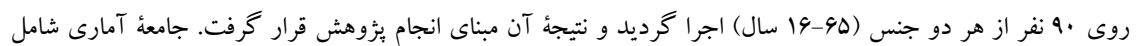
افراد بين 10 10

سال (با ميانگين و سال) است كه ه ماه ساكن شهر ايلام بودند. درنهايت، تعداد نمونها برابر ..9 نفر به مقدار مساوى از

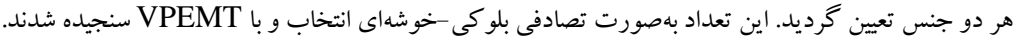

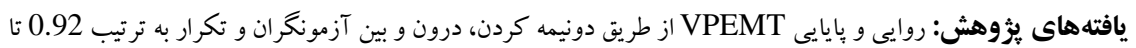

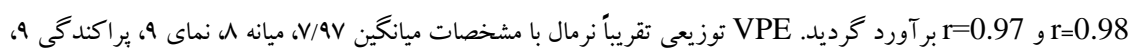

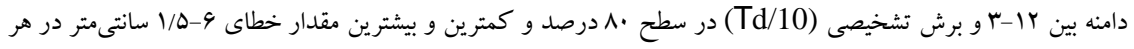

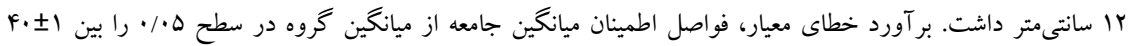

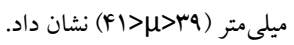
بحث و نتيجه كيرى: بر اساس يافتهاى يزوهش مىتوان نتيجه گرفت كه VPEMT در نشان دان دان دادن مقدار خطاى ادراك

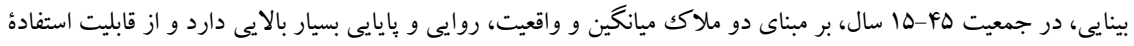

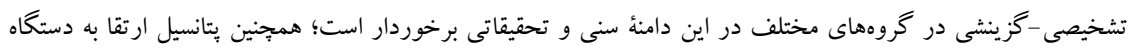

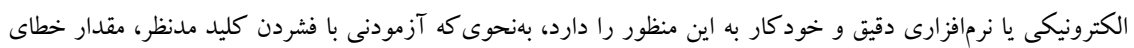
ادراكك خويش را دريافت كند. كروه روانشناسى، دانشكاه آزادي اسلامى، واحد بروجرد، بروجرد، ايران انسان، Email:

Akbar_malel2002@yahoo.com

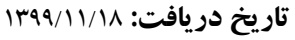
تاريخ داورى: س.ب/T تاريخ يذيرش: F/FF/VF

نويسنده مسئول:

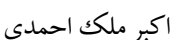

هر


محققان با تمركز روى سامانهُ بينايى و بهرهگيرى از رويكردهاى بيازماى، روانسنجى و يردازشى به مطالعات

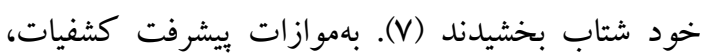
نظريههاى بسيارى در توجيه جخگونكى سازو كارهاى

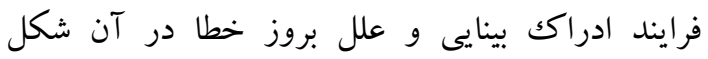

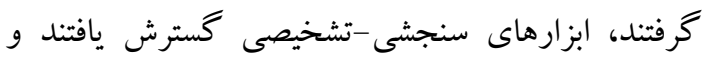
وقوع خطاهاى ادراكى متعدد طى فرايندهاى شناختى و

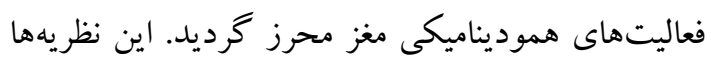
در جهار دستهُ كلى قرار مى گيرند:

الف. نظريههاى جهتدار و تلفيقى: مانند نظريههاى

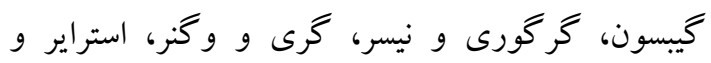

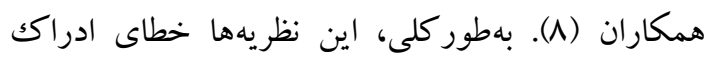
بينايى را ناشى از نوسان در اطلاعات ورودى، انتخاب و فرضيهآزمايى مغز مىدانند؛ اما فرضئ كمبود اطلاعات دربارهٔ خطاى مويلر -لاير رد شد (9). ب. نظريههاى نمادى: شامل نظريههاى نمادهاى هندسى بيدرمن، ثبات شيب خطاى بصرى گو گل، ثبات هندسى بيز (•))، خطوط هندسى و محاسباتى مار و نظرئ يردازش عمق خطاى يو كندروف كه بيشتر خطاى ادراك هن

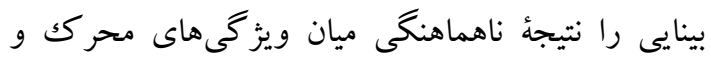
وضعيت حركتى بدن ناظر تصور مى كنند. برخى اين نظر را نيز دربارةٔ خطاى مولر-لاير رد كردند (11).

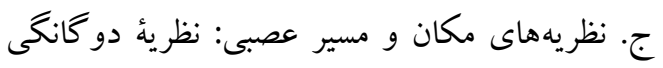

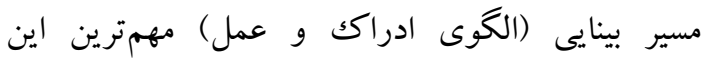
نظريههاست. بر اساس آن، ادراكك بينايى دو مسير مغزى

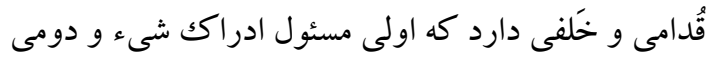

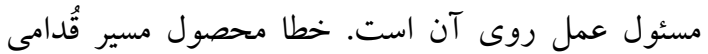

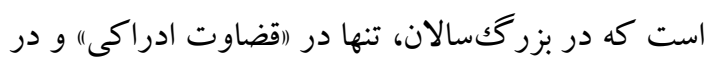

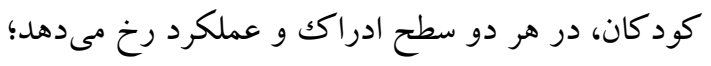

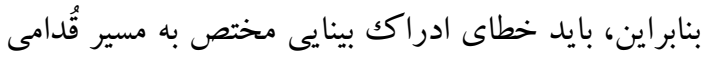

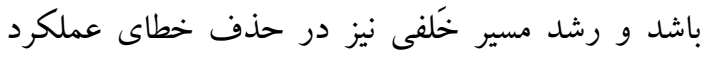

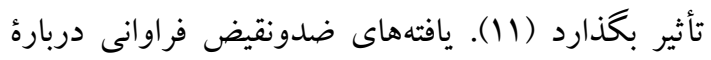
اين نظريه وجود دارد. برخى محققان مانند گرى و وانئهاي
ادراك فرايند ذهنى بيجيجيده و سريعى است كه در آن، اطلاعات حسى به همراه تجارب بيشين تجزيه وتحليل و معنادار مىشود و از آن روابط امور و معناى اشيا دريافت مى گردد. مهارتهاى ادراكى بينايى شامل توانايى شناخت، انتخاب، سازماندهى و تفسير اطلاعات ديدهشده

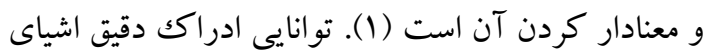
محيط و جهان خارج لازمة زندگى است و نقش بسيار مهمى در ارتباط موفق موجود زنده با محيط خود دارد. در

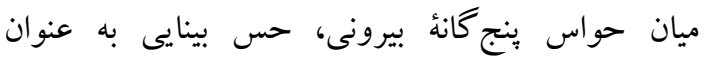

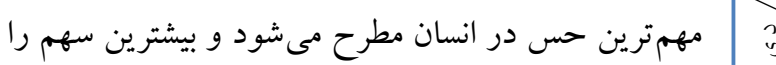
در انتقال اطلاعات ادراكى بر عهده دارد؛ تا جايى كه

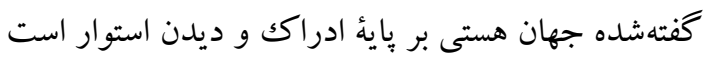

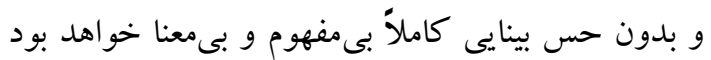

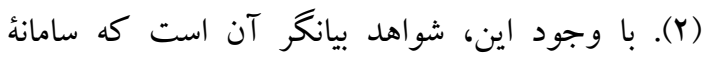
ادراكى در اين فرايند تعاملى دجار خطا مىشود و قادر نيست واقعيت عينى اشيا را به ما منعكس كند. هزاران سال است بشر به وجود خطاهاى ادراكك بينايى آكاهى دارد (T). خطاى ادراك بينايى معادل تفاوت ميان برداشتهاى

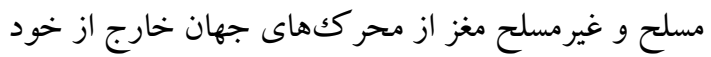
تعريفشده است (F). محققان سهم سامانه بينايى در انتقال اطلاعات و يادگيرى را ·V تا •N درصد دانستهاند كه بيانكر تمركز تحقيقات ادراكى روى اين سامانه است (Y). شواهد نشان مىدهد كه يككسوم قشر مغز در يردازش محر كك هاى بينايى نقش دارد (ه) و بيش از ·ـ ناحئ بينايى مختلف در مغز به بردازش اطلاعات اين سامانه اختصاص دارند (9) بنابراين، بهعنوان بهترين راه مطالعهُ فرايندهاى شناختى مغز بهشمار مى آيد. تاكنون بيشترين يافتهاى بـاي

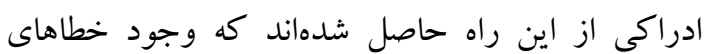
ادراكى در ابعاد مختلف اشياء ازجملة آنهاست (F). خطاى مويلر-لاير يكى از اين خطاها است كه فرانتز

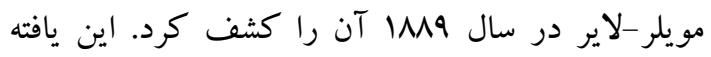
بهعنوان بايأ محكم و قابل اعتمادى، موردتوجه و استفادة

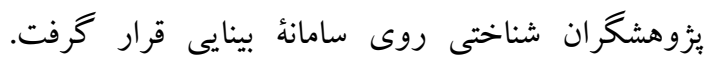


كرديد (F). جشمانداز اين نتايج، لزوم تجميع يثزوهشخران رشتهاى مختلف در اين حيطه را در قالب رشتئ علوم

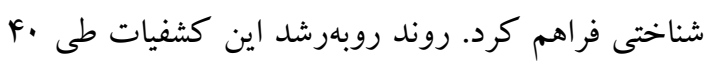

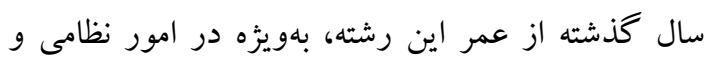

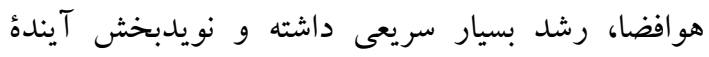
درخشان آن است، بهنحوى كه امروزه، برخى دانشمندان علوم شناختى را قلب علوم نوين و بيل ميان علوم انسانى و

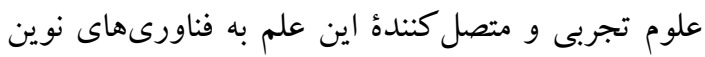
معرفى مى كنند (YD) و تحقيقات روى خطاهاى ادراك بينايى را راه افزايش دانش علوم عصبى، مهندسى اعصاب

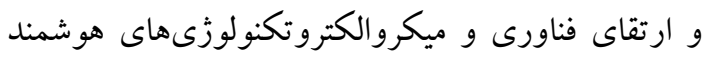
مىدانند (F). بر اين اساس، متخصصان علوم مهندسى اعصاب، رايانه و دستكاههاى هوشمند سعى دارند با لـان

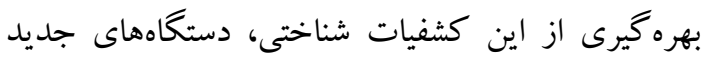
رادارى و فرماندار را به گونهاى طراحى كنند كه وقوع آن سوانح ناشى از خطاهاى ادراكى در امور نظامى و هو افضا را به حداقل برسانند (Y)). با اين اوصاف، تحقيقات شناختى اخير بيشتر بر سامانه بينايى متمركز است و نظريهها و ابزارهاى فراوانى بدين منظور شكل گرفته، ساخته شده و بسيارى از خطاهاى منتسب به اين سامانه شناسايى شدهاند. سامانه ادراك

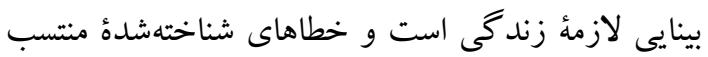

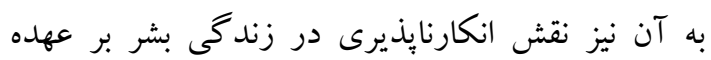

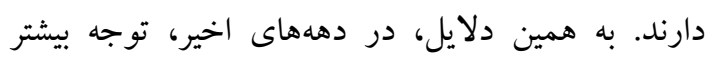

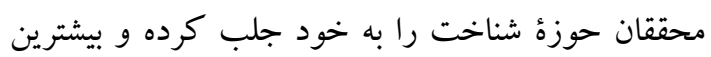

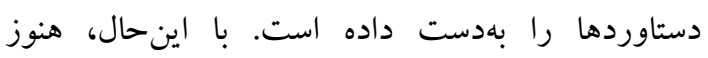
يرسشهاى فراوانى دراينباره وجود دارند كه تاكنون باسخى علمى دريافت نكردهاند.

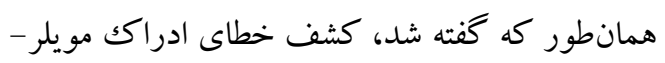
لاير يكى از نتايج مطالعات روى سامانه بينايى بود كه

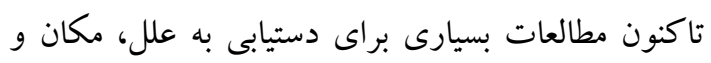

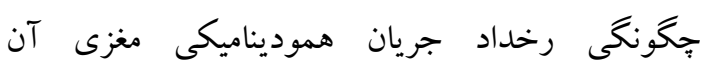
انجامشده است، بهطورى كه راسكين (به نقل از حسينا)

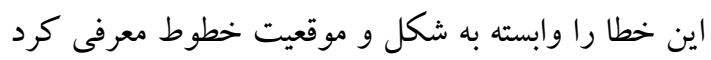

همكاران و كوييسك و همكاران، فرضيئ دو كانكى مسير

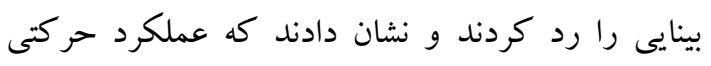

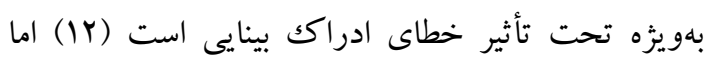

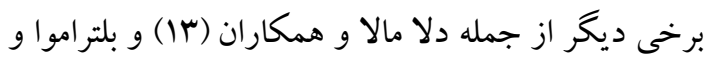

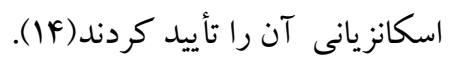

د. نظريههاى تداخل اطلاعات: تئورى تشخيص

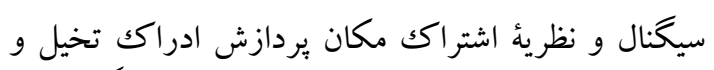

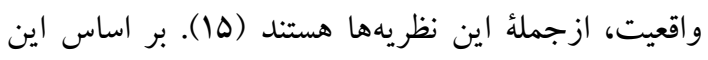
نظريهها، خطاى ادراكى بينايى نتيجه تداخل اطلاعات

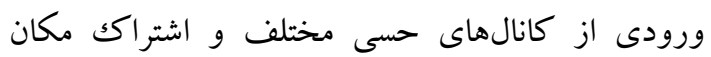

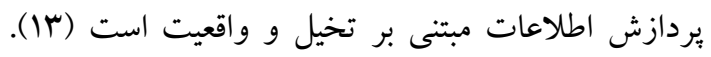

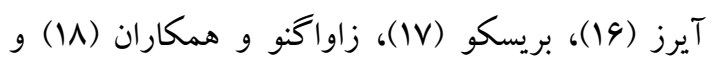

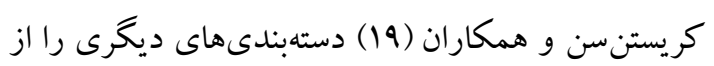

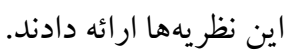
تقريباً همهٔ اين نظريهها وجود خطا در فرايند ادراك ادرك

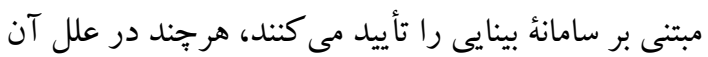

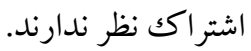
آزمونهاى مويلر - لاير و آزمون استروب، تعقيب

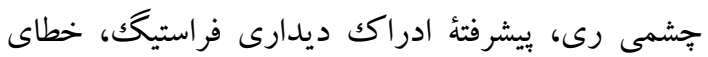

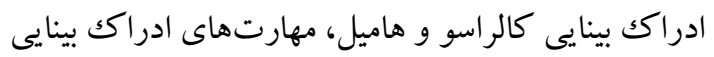

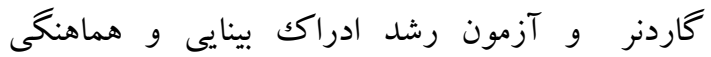
ديدارى-حر كتى هاميل و همكاران ، سامانه آزمون زمان

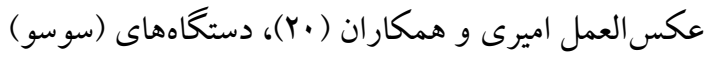

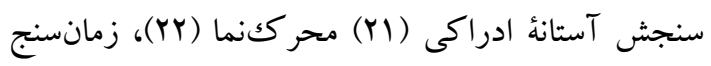
واكنش ارادى، طيف نگار كار كردى نزديك مادونقرمز ادرالئ

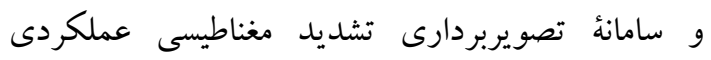

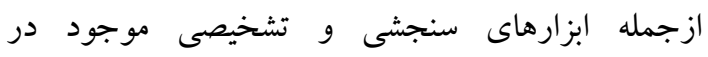

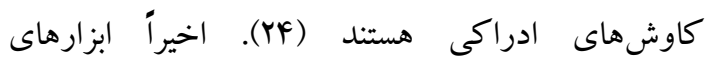

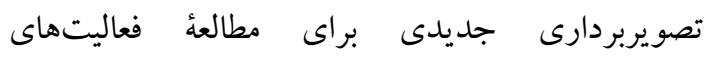

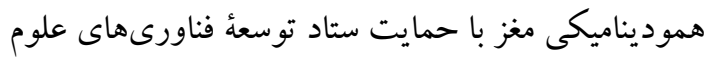
شناختى ماند ISOI نيز توليد شدهاند (YD). همانطور كه بيان شد، مطالعات ادراكى روى سامانه بينايى متمركز و به كشفيات و نتايج متعددى ازجمله خطاهاى موجود در جريان فرايند ادراك بينايى منجر 
بدون استثنا وجود دارد يا خير؟ ب. توزيع اين متغير در

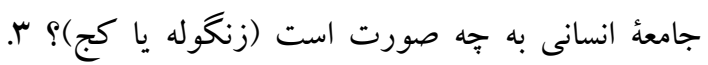
ميانخين و دامنههاى خطاى مويلر-لاير در جه فواصلى نسبت به واقعيت (ملاكك) قرار مى گيرند؟ دئن

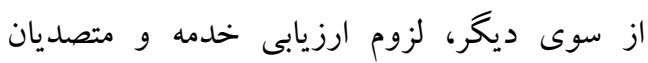
بستهاى حساسى جون خلبانى، دستخاههاى الكترونيك إنى

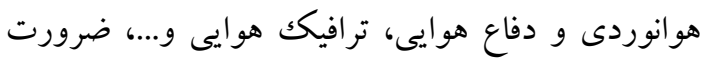

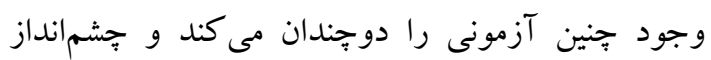
مناسبى در كاربرد آن بهجاى دستگاههاى حجيم دوني

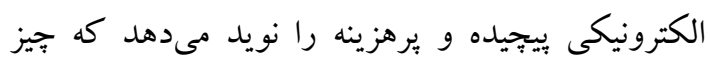
دقيقى دراينباره هم نشان نمىدهند.

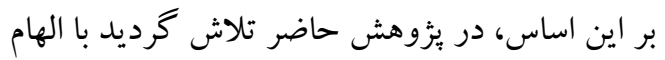

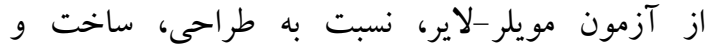
هنجاريابى ابزارى كاملاً جديد با عنوان آزمون سنجش لرّل خطاى ادراكك بينايى (VPEMT) برداخته شود كه قادر به انجام آزمون فرضيات زير براى يافتن باسخ يرسشهاى بالا باشد و زمينه را براى تحقيقات بعدى فراهم كند.

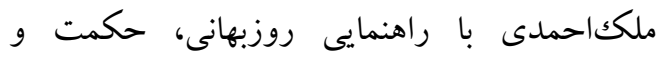
مشاورة صادقى (·r.Y.Y)، اين آزمون را كه به اختصار " "

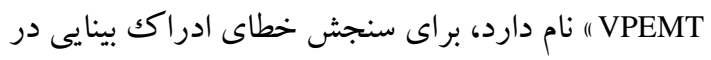
اندازهُ طول برحسب ميلىمتر ساخت؛ بنابراين، فرضيههاى

$$
\text { يثزوهش حاضر به اين صورت بيان مى شوند: }
$$

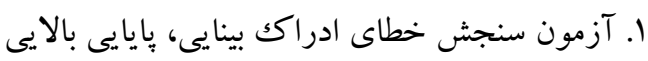
براى سنجش خطاى ادراكك بصرى در بر آورد اندازهُ طول بائي باليى

$$
\text { دو يارهخط مساوى (T) نسبت بههم را دارد. }
$$

r. آزمون سنجش خطاى ادراك بينايى از روايى كامل براى سنجش خطاى ادراكك بصرى در بر آورد اندازهُ طول

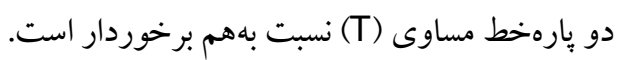
r. خطاى ادراك بينايى بر آوردشده توسط اين آزمون

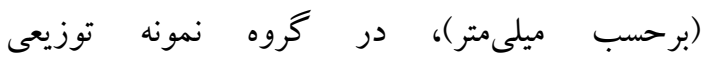
زنكو لهاىشكل دارد.

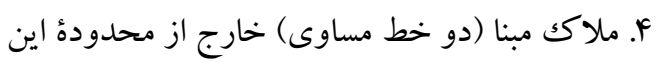
توزيع قرار مى گيرد.

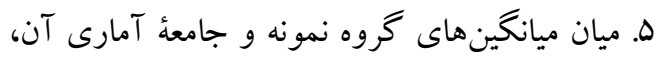

(YV) نيمكرههاى مغز بيى بردند؛ بهعبارتديخر، آنان دريافتند

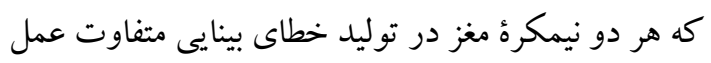

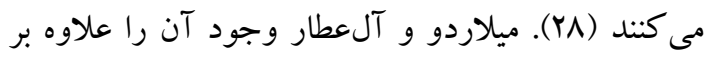

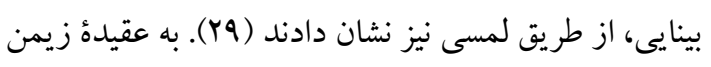

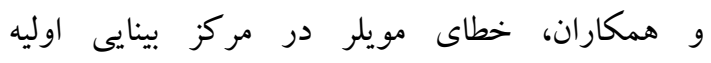
(ساختارهاى تالاموس) رخ مى دهد و نه در مركز ثانويه.

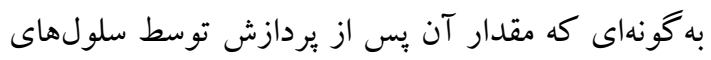
ساده، افزايش و يس از يردازش توسط سلولهاى بيجيجيده،

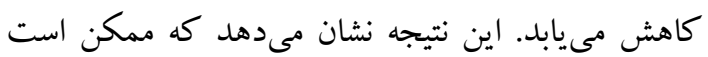

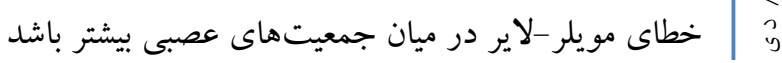
(9). اين شواهد وجود خطاى مويلر در سامانهُ ادراك بينايى را بهعنوان اصلى يذيرفتهشده مىنماياند كه

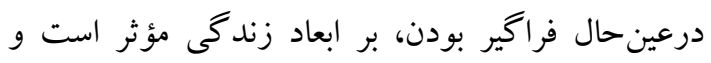
قابليت تشخيص دقيق و سريع توسط آزمون مويلر رادارد؛

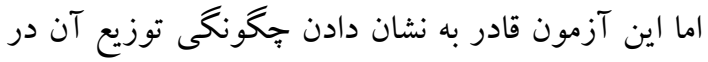
جامعه نيست و دربارةٔ علت يا علل آن نيز يافتههاى ضدونقيض فراوانى وجود دارد و تاكنون مبناى تحقيقات

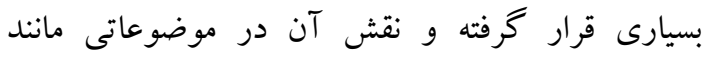
حوادث ترافيكك زمينى و سوانح هوايى، اختلالات

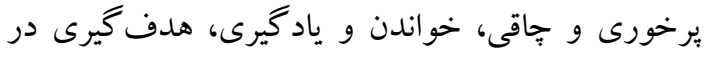

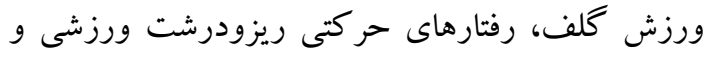

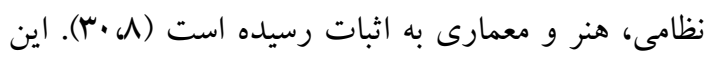

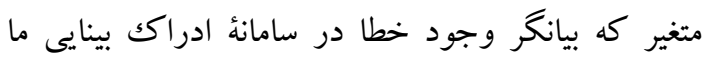

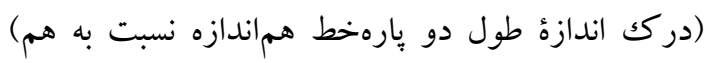
است، امرى بذيرفتهشده است و نيازى به اثبات دوباره

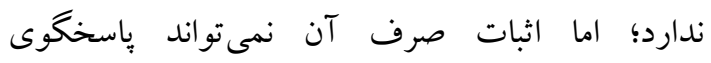

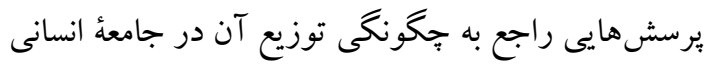
باشد؛ بنابراين، انجام مطالعات جديد براى به اين منظور امرى لورى ضرورى بهنظر مىرسد و لازمهٔ تحقق آن، وجود ابزارى

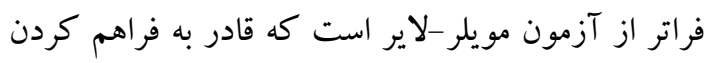
پاسخ پرسشهاى زير باشد؛ اما بر اساس بررسىهاى

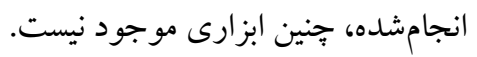
ا. آيا خطاى مويلر بهعنوان يكك متغير در همه انسانها 
يز شكىى، آزاد) و جهار دبيرستان (Y بسرانه و Y دخترانه)

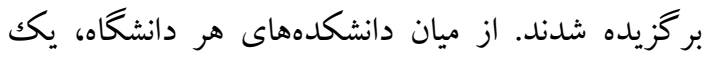

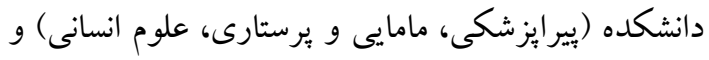

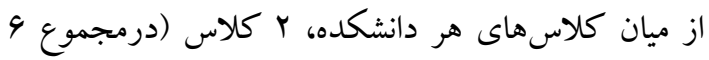

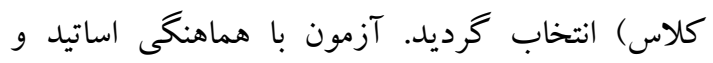

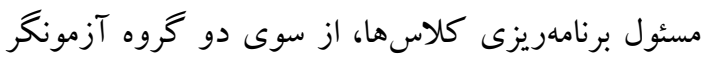

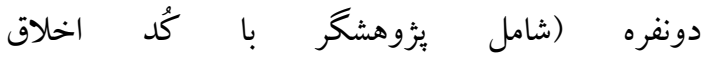

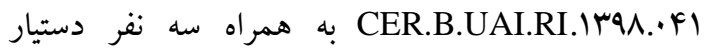
دانشجوى آموزشديده) بهصورت گروهى (ياور - اسلايد)

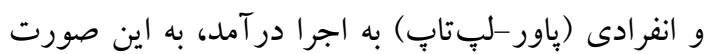

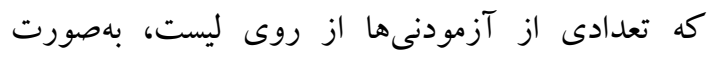
تصادفى انتخاب گرديد و از آنان آزمون انفرادى گرىفنه شد و سايرين بهصورت گروهى آزمون دادند. در بلوك آنك

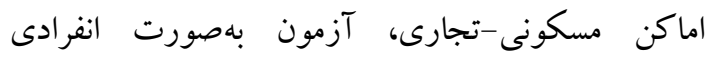
صورت گرفت، بهاينترتيب كه با مراجعه به اين اماكن

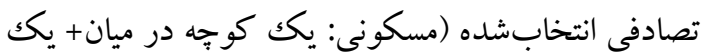
خيابان تجارى)، آزمون روى افر اد دردسترس اجرا شد. با توجه به حجم تقريبى rarrqG نفرى جامعd آمارى_ برحسب رشد Y درصدى سالانه جمعيت بر مبناى

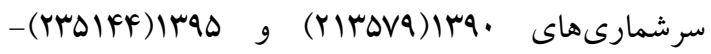
كمترين برآورد نرمافزار كوكران (

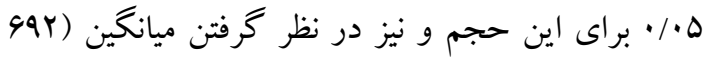

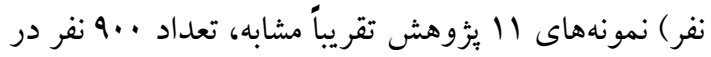

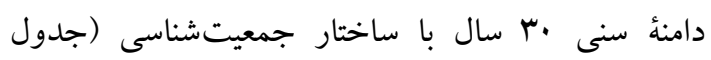
شمارؤ ()، بهعنوان نمونه انتخاب و به كار گرفته شد. ملاككهاى ورود آزمودنىها عبارت بودند از: قرار

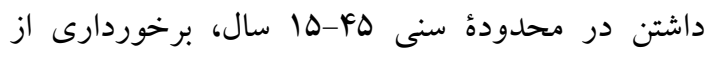

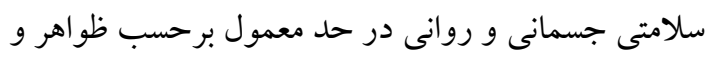

از نظر خطاى ادراكك بينايى، تفاوت معنادارى وجود

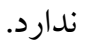

\section{مواد و روش ها}

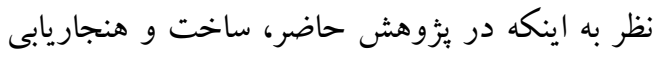
آزمونى براى اندازهگيرى خطاى ادراكى بينايى به انجام

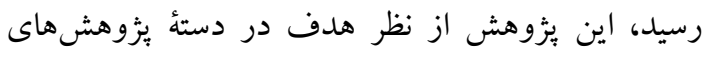

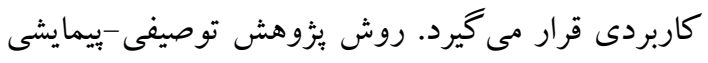

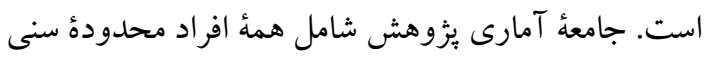

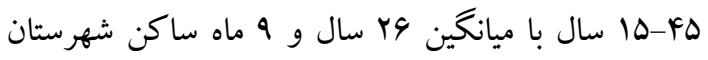

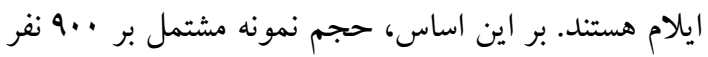

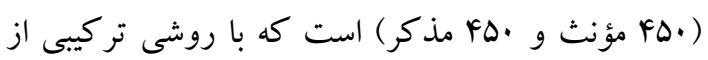

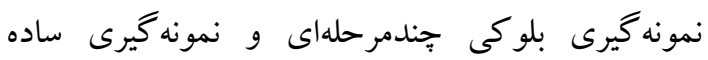
انتخاب شدند. با توجه به حجم و دامنه سنى نمونه و جمعيتشناختى جامعه آمارى (جدول شماره ())، براى انتخاب نمونه، ابتدا همةٔ اماكن شهر به سه بلوكك (اماكن مسكونى-تجارى، اماكن ادارى و اماكن آموزشى) تقسيم

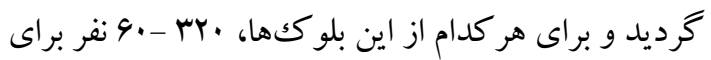

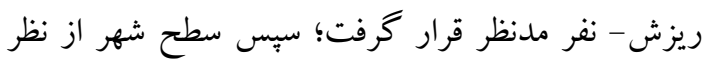

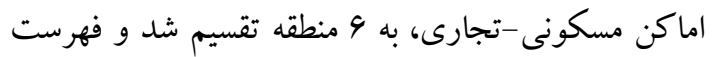

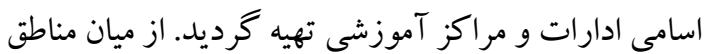
مسكونى-تجارى شش كانه، بهصورت تصادفى يكك منطقه و از ميان ادارات، شش اداره (كه متأسفانه علىرغم صدور دستور و مجوز لازم، در مرحلة اجرا با ما همكارى

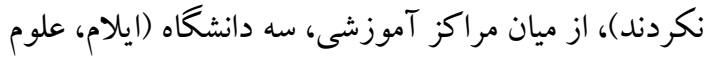

جدول شماره ا. دامنه سنى و تحصيلى كل آزمودنى ها

\begin{tabular}{|c|c|c|c|c|c|c|c|c|}
\hline جمع & بع سواد & زير دييلم & ديبلم & كاردانى & كارشناسى & ارشد & دكترى & تحصيلات/ دامنه سنى \\
\hline Drq & 1 & rru & $r$ r. & kr & rq & $\Delta$ & . & $10-r_{0}$ \\
\hline 101 & If & rr & TD & 19 & r & $\Delta 1$ & r & rq-ro \\
\hline r.9 & ru & 19 & ro & 9 & FV & $\Delta 1$ & IV & $r_{4-F \Delta}$ \\
\hline q.. & $\mathrm{Fr}$ & roq & ҮA. & 91 & IYF & $1 . v$ & 19 & جمع \\
\hline
\end{tabular}


اجرا و محرمانه و بىضرر بودن آزمون، كاملاً توجيه و

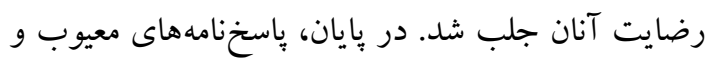

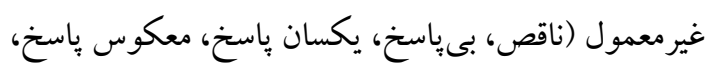

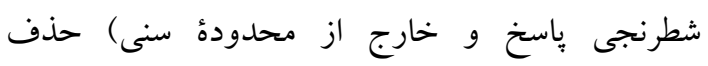

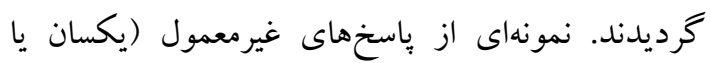

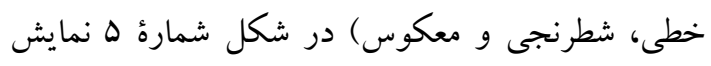
دادهشده است.

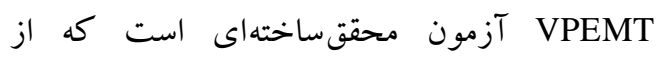

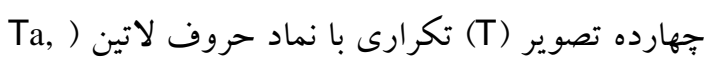
تشكيل شده است. هر تصوير متشكل از دو (Tb...Tn يارمخط افقى (الف) و عمودى (ب) است. در ميان اين

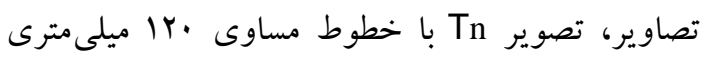
به عنوان معيار و ملاكك محسوب مى شود و ساير تصاوير

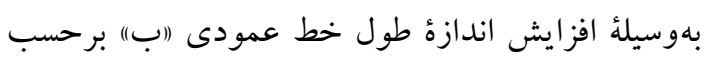

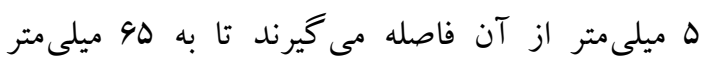
تفاوت (Ta) نسبت به خط افقى (الف) منتهى مى گر دمد.

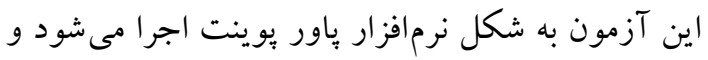
طورى طراحىشده است كه بتوان براى جلو گيرى از از پاسخخ حدسى، اين نمادها را از ديد آزمودنى ينهان

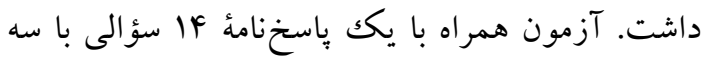

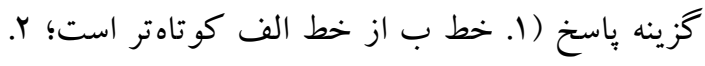

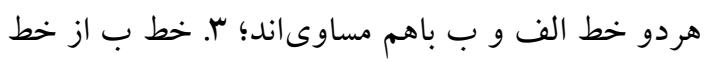

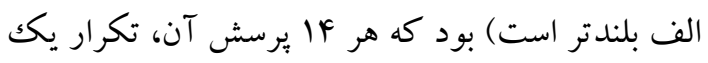

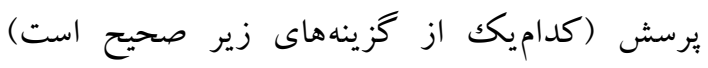

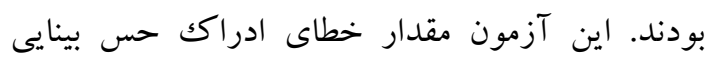

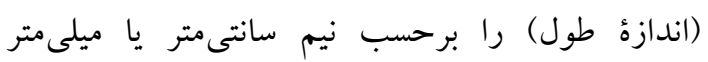
اندازه گيرى مى كند. گفتنى است براى كنترل اثر زمينه،

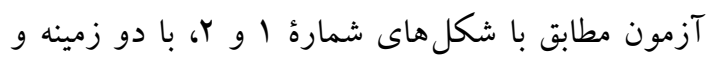
شكل متضاد اجرا شد. شيوه نمره گذارى به شرح ذيل است: نمرة اين آزمون برحسب ميلىمتر و بين 90-· يا برحسب نيم سانتىمتر

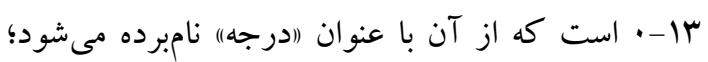

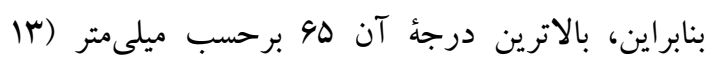

خوداظهارى و نظر محقق بهعنوان كسى كه بيش از If

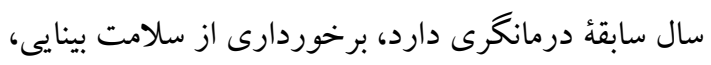

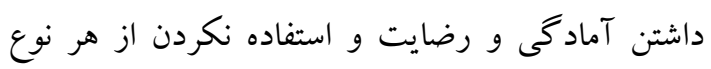

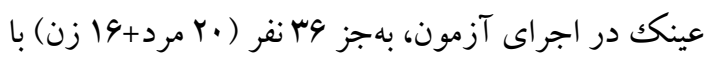
عينك طبى كه نمرات آنان بهمنظور فهم اثر نقص بينايى و تفكيكك ميان ادراكك و حس بينايى، بهصورت جدات اندانه تجزيهو تحليل گر ديد. ملاكك هاى خروج آزمودنىها عبارت بودند از: داشتن

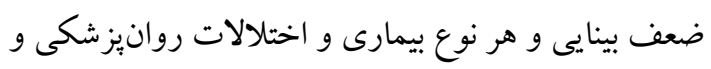
مغز و اعصاب مشهود محسوس، خارج بودن از محدودهء

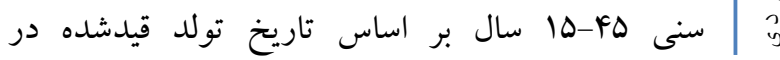

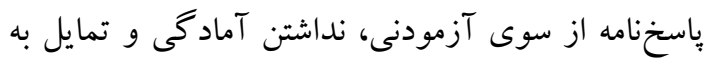

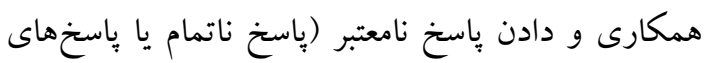

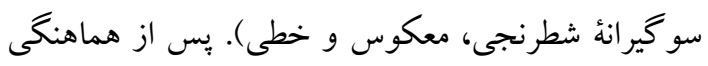

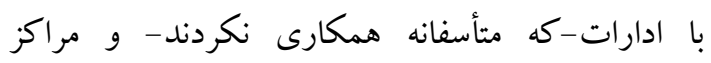

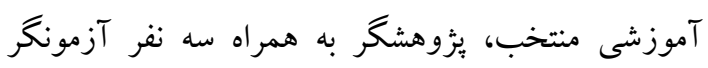

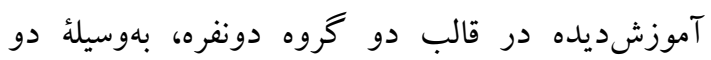

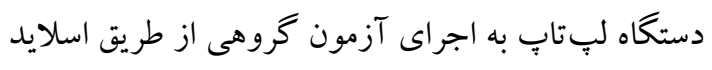

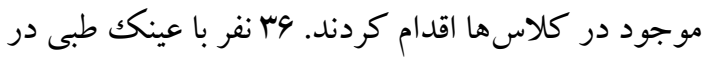

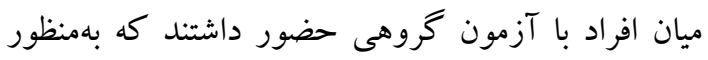

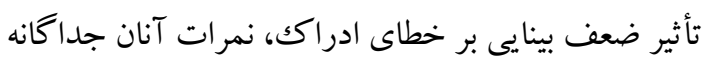

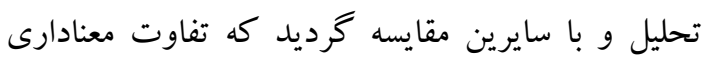
ديلده نشل.

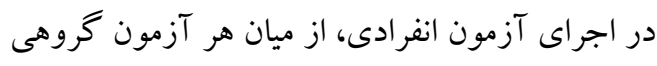

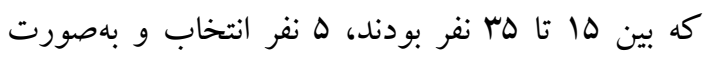

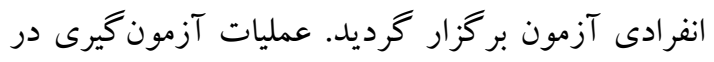

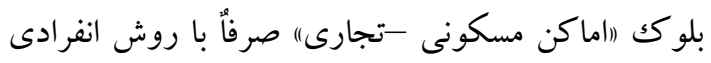
از سوى دو گروه انجام گرفت. براى اين كار، منازل بهصورت يك كوجه در ميان و مراكز تجارى يكك خيابان در نظر كفته شد. بهمنظور بايايى آزمون، بـ إن از يكك ماه

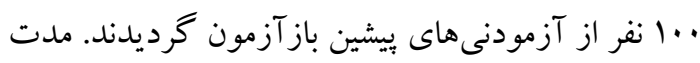

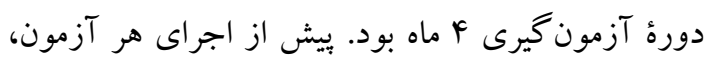

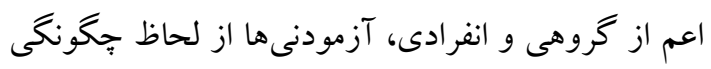




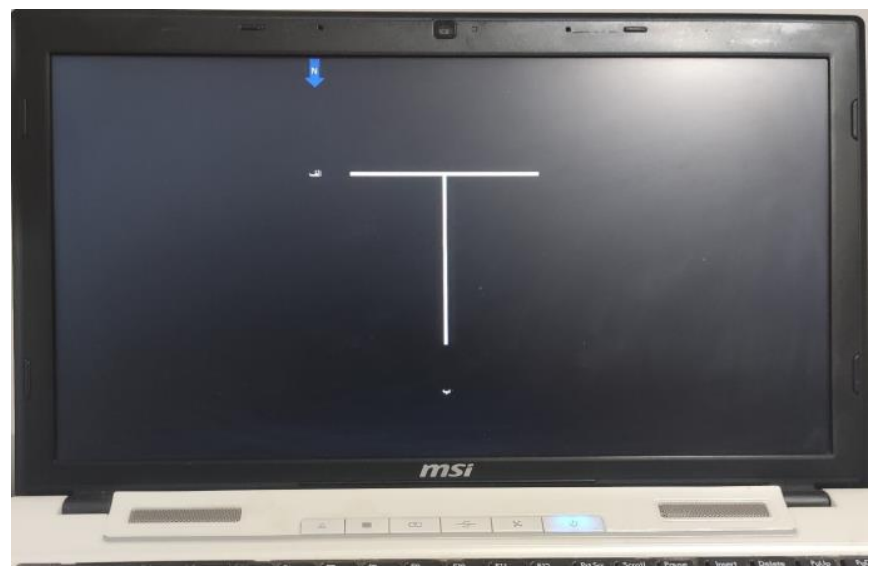

شكل شماره ا. اجراى آزمون با محرك سفيد و زمينه سياه

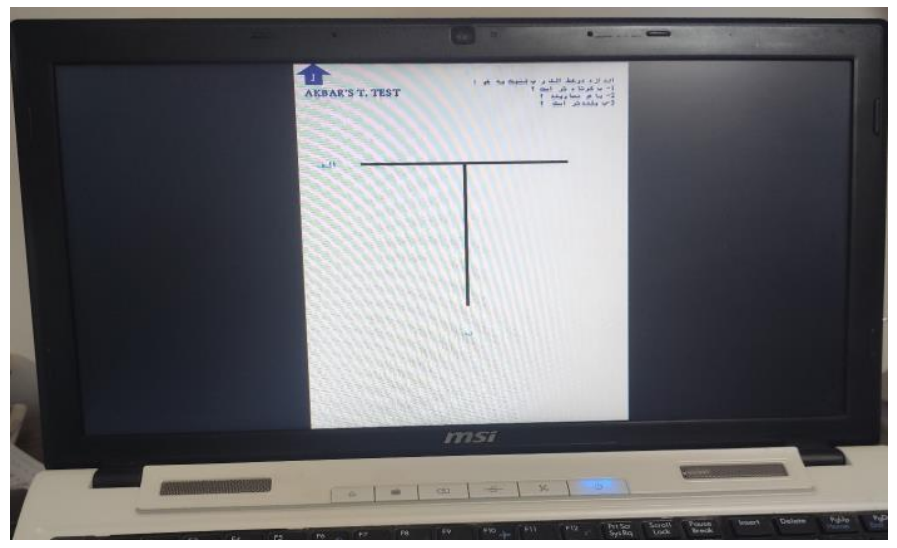

شكل شماره Гا. اجر ایى آزمون با محرك سياه و زمينه سفيد

مقايسٔ بين آزمونگُ ان، دونيمه آزمودنى، گروهى و انفرادى، جنسيتى، با و بدون عينكك، زمينهُ سياه و زمينهُ سفيد، طبقات سنى و يايايى آزمون نيز از طريق باز آزمون صد نفر منتخب تصادفى از روى ياسخنامه و و با فاصله زمانى يكك ماه، همجِنين مقايسه نتايج آزمون مقدماتى با نتيجهُ آزمون اصلى (به فاصلة يكك سال) محاسبه شد. براى تعميم نتايج بهدست آمده، از رويكرد فاصلهاى بهجاى رويكرد نقطهاى بهوسيلة SPSS vol.23 استفاده كرديد (جدول شمارهء () كه اين نتيجه بيانكر آن است كه a- ميانگين جامعd آمارى با اطمينان ه9 درصد و در سطح 1، در فاصلة يكك ميلىمترى (I士 (F) ميانگين نمونه قرار مى گيرد؛ بهعبارتديخر، اين يافته با سطح اطمينان هو درصد و حاشيه خطاى ه درصد، قابل تعميم به جامعهُ افراد بين DQF-D سال است و فرضئ صفر مبنى بر تعلق نداشتن نمونه به جامعهُ آمارى را با هو درصد احتمال رد مى كند.
برحسب نيم سانتىمتر) و كمترين درجه برابر صفر است. هر درجه برابر تفاوت اندازه طول خط ب نسبت به طول خط الف در هر تصوير (T) است. درجه معادل مقدار خطا است؛ يعنى هرجه درجهُ فرد در آزمون بيشتر باشد، به همان اندازه خطاى ادراكى بصرى بيشترى دارد. مهلت ياسخكويى به هر تصوير ها ثانيه، استراحت بين هر تصوير نيز ها ثانيه و كل زمان آزمون V دقيقه است. نمره هر فرد (درجهُ خطاى ادراكك بينايى)، مقدار تفاوت دو يارهخط (الف/ب) در تصويرى (T) است كه اولين بِاسخ (اندازهُ هردو خط الف و ب باهم مساوىاند) را توسط او

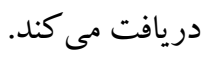
هرجند كه اين آزمون، به علت ماهيت بزوهشى، ازجمله تككسؤالى بودن و تكرار آن، به برآورد روايى درونى و بيرونى نياز نداشت، بالينحال، روايى و بايايى آن به شرح جدول شمارهُ بهدست آمد. روايى آزمون با 
جدول شماره ז. ضر ايب همبستى بيرسون

\begin{tabular}{|c|c|c|c|c|c|}
\hline زمان اجرا & \multicolumn{2}{|c|}{ تعدادآزمودنى ها } & مقدار ضريب & موارد همبسته & آزمون \\
\hline همزمان & ra. & $r \Delta$ & $\mathrm{r}=\cdot / 9 \mathrm{r}$ & بين آزمونگران & \\
\hline$=$ & ro. & to. & $\mathrm{r}=\cdot / 9 \Delta$ & دو نيمه آزمودنى & \\
\hline$=$ & rar & orr & $\mathrm{r}=\cdot / 9 \mathrm{q}$ & كروهى و انفرادى & \\
\hline$=$ & $\Leftrightarrow \Delta$. & cos. & $\mathrm{r}=\cdot / 99$ & بين جنسيتى & \\
\hline$=$ & $\Lambda G F$ & rq & $r=\cdot / 9 \Delta$ & با و بدون عينك & \\
\hline$=$ & FFY & FOA & $r=\cdot / 91$ & زمينه سياه و سفيد & VPEMT \\
\hline$=$ & 101 & $\Delta F F$ & $r=\cdot / 9 r$ & طبقات سنى & \\
\hline$=$ & $r \cdot \Delta$ & $\Delta F F$ & $r=\cdot / 9 r$ & $r q-r \Delta, \mid \Delta-r \Delta==$ & \\
\hline$=$ & $r \cdot \Delta$ & 101 & $r=\cdot / 9 \Delta$ & $r G-F \Delta$, YG-rD = & \\
\hline با فاصله يك ماه & $1 .$. & $1 .$. & $\mathrm{r}=. / 9 \mathrm{~V}$ & بيش و پِس آزمون & \\
\hline يكسال & 9. & $9 \cdot$. & $r=/ A r$ & آزمون مقدماتى و اصلى & \\
\hline
\end{tabular}

جدول شماره Гا. برآورد خطاى معيار ميانخين و انحراف معيار جامعه بر حسب ميليمتر.

\begin{tabular}{|c|c|c|c|c|c|c|c|}
\hline انحر اف معيار & \multicolumn{2}{|c|}{ ميانكين } & حد بالا & حد بإيين & دامنه & آزمودنيها & \\
\hline شاخص & خطاى معيار & شاخص & شاخص & شاخص & شاخص & شاخص & \\
\hline \multirow[t]{2}{*}{9} & 1 & r. & 9. & 10 & $\varphi_{\Delta}$ & $9 \cdot$. & كل \\
\hline & & & & & & $9 .$. & تعداد معتبر \\
\hline
\end{tabular}

درجة مقياس)

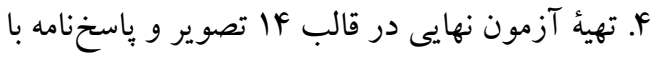

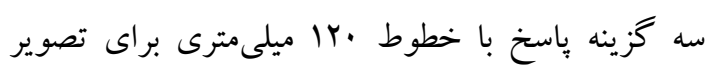
ملاكك؛ ه. اجراى آزمون نهايى و بررسى تعيين بايايى، روايى،

$$
\text { ميانكين، دامنه و تعميم به جامعه. }
$$

يافته ها

با توجه به دادههاى جدولهاى شمارة ا و Y مى توان كفت كه آزمون سنجش خطاى ادراك بينايى از روايى

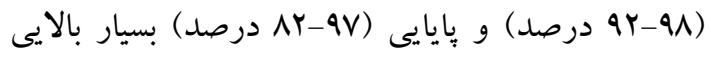

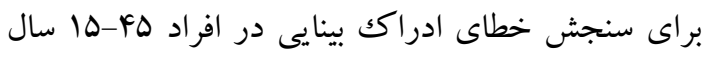
برخوردار است.

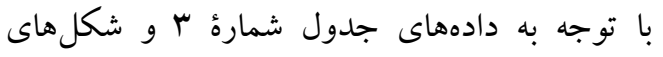

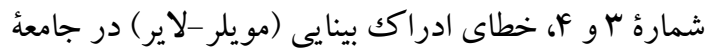

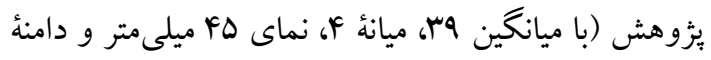

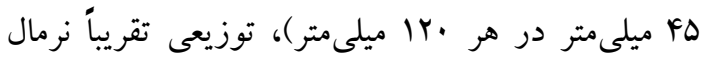

مراحل ساخت و روش آزمون: اين آزمون عمدتاً بر اساس نظريههاى ادراكك بينايى بهويزه خطاى مويلر -لاير،

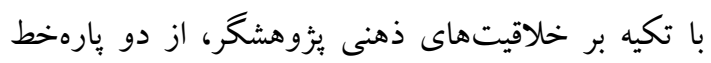

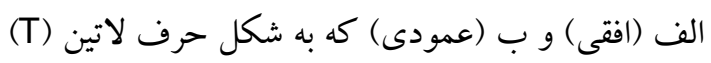

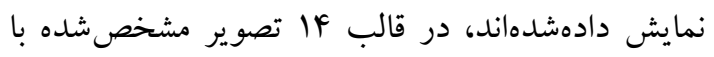
حروف لاتين كوجّك (Ta,Tb,...Tn) بهصورت نرمافزار باور بوينت طراحى شد. بر اساس اين، براى ساخت و اعتباريابى آزمون مر احل زير طى گرديد: ا. بررسى مبانى نظرى، ادبيات تخصصى و ويشينئ تحقيقاتى داخلى و خارجى

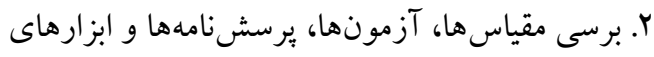

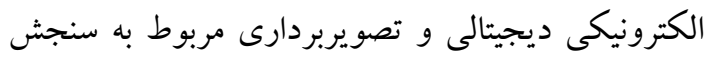

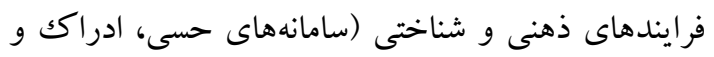
خطاهاى ادراكى) و زمينهاى وابسته در حوزهُ علوم شناختى ام. تهيه و اجراى آزمون مقدماتى و حذف و تغيير و

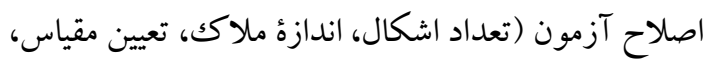




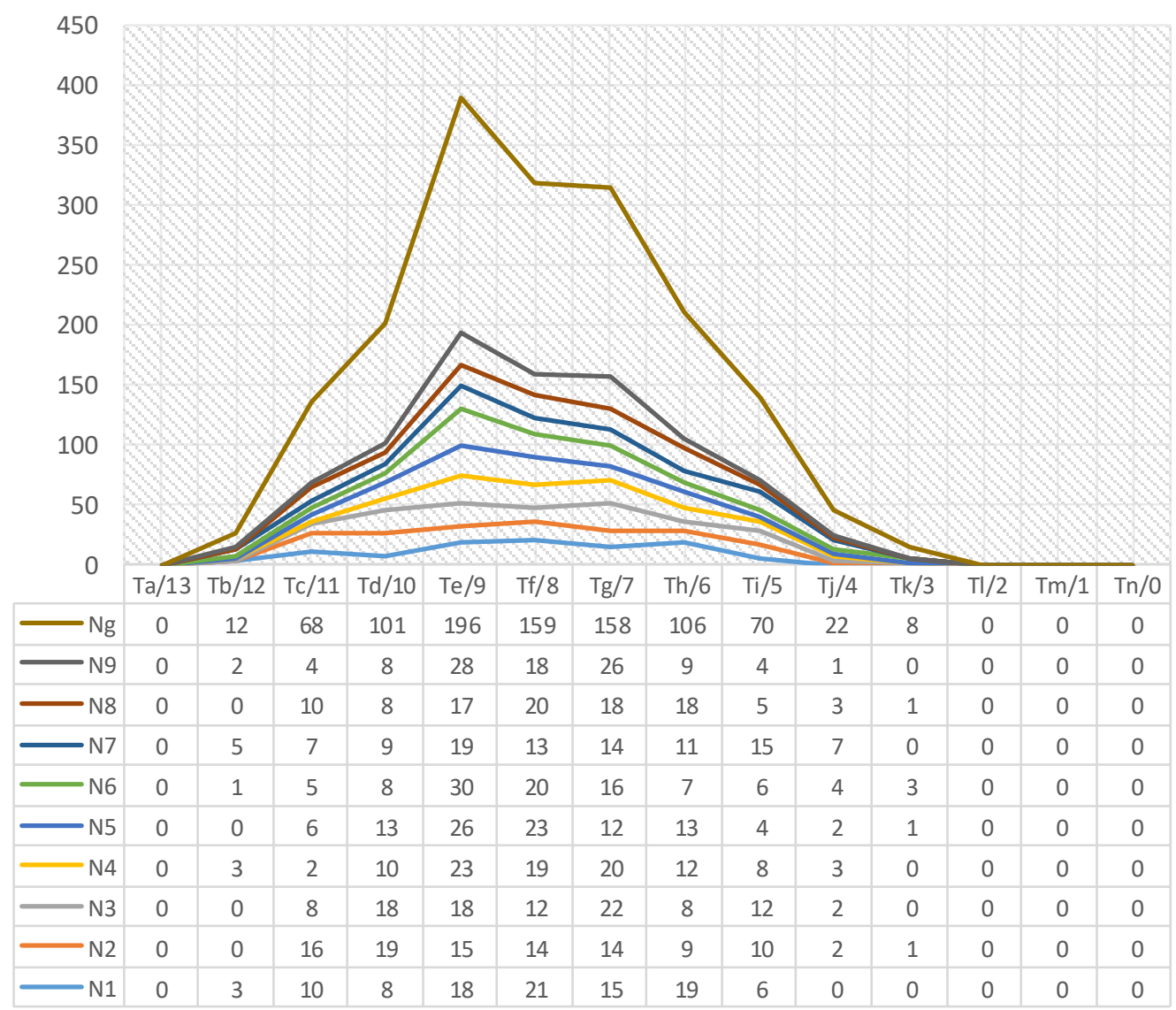

شكل شماره rا. توزيع نمونه خيرى

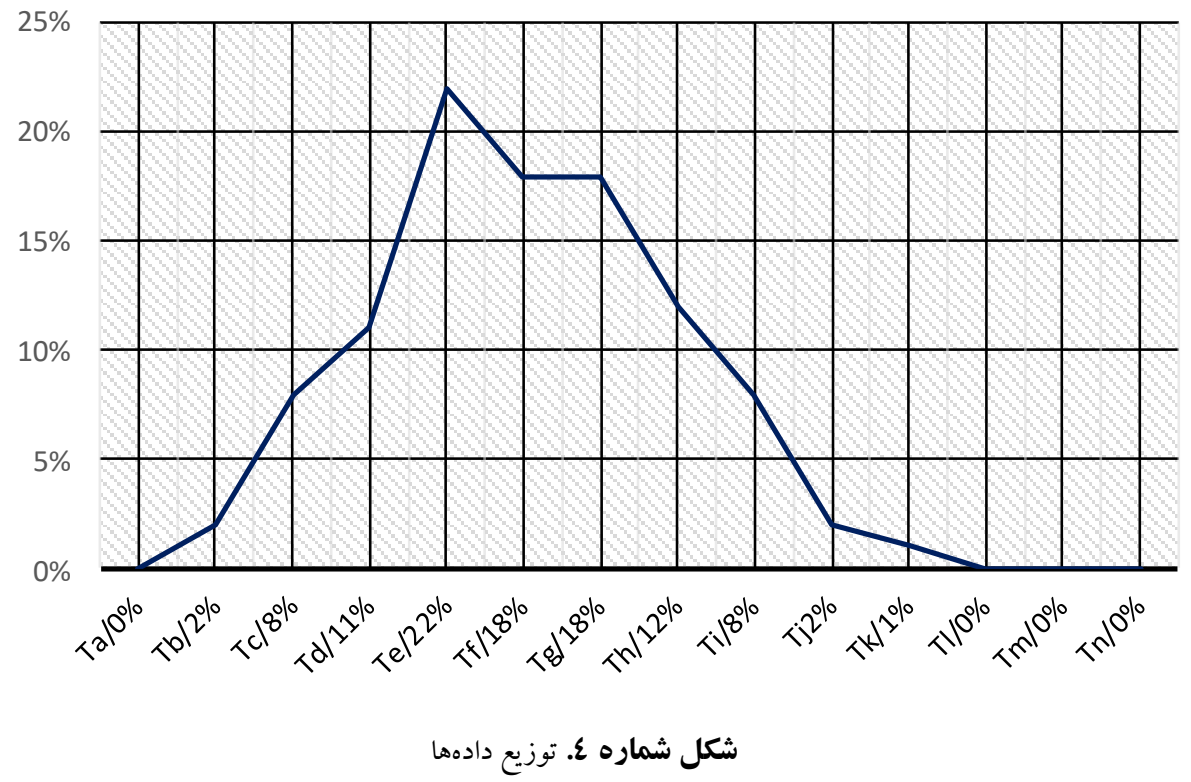

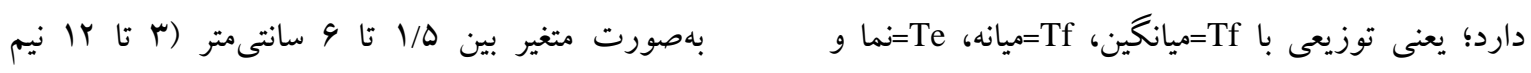

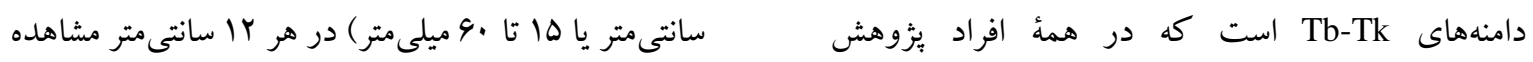




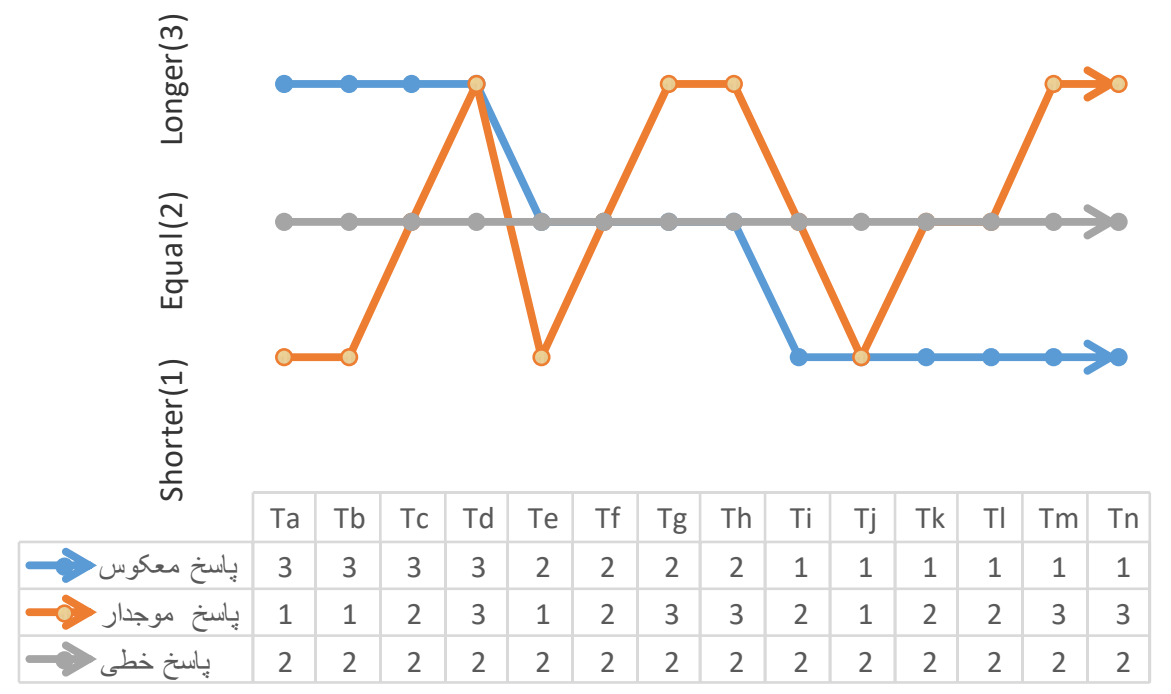

شكل شماره 0. باسخ هاى معيوب

تمايلى به انجام آزمون نداشته و صرفاً همكارى ظاهرى نشان داده است. شخص شطرنجىياسخ، سو كيرى يا ناسيا

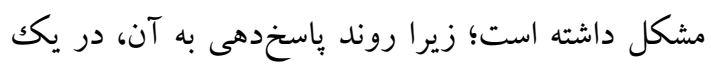

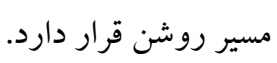

بحث و نتيجه كيرى

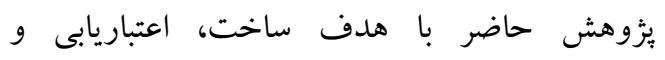

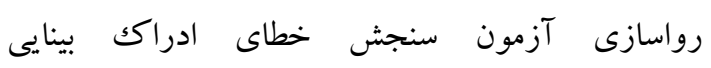

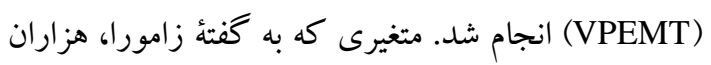

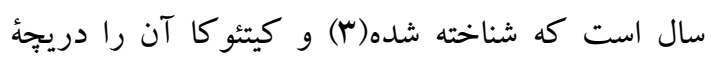

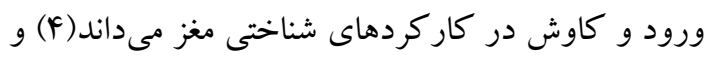
تاكنون مبناى هزاران تحقيق قرار كرفته است.

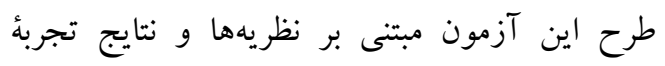

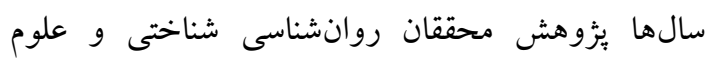

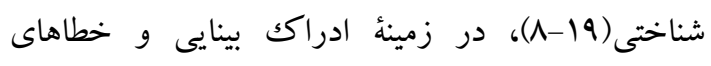

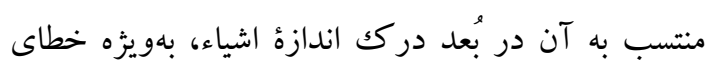

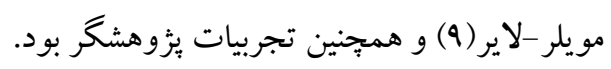
بررسىها نشان داد كه در حيطة ادراككسنجى بينايى،

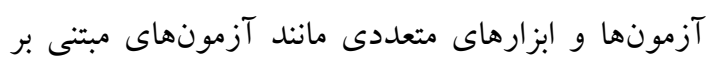

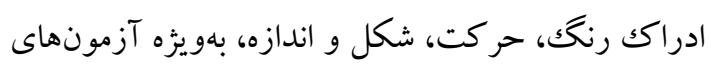

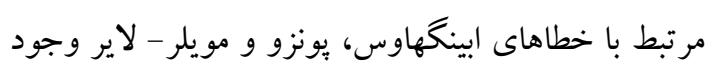

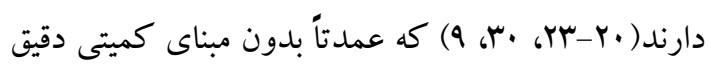

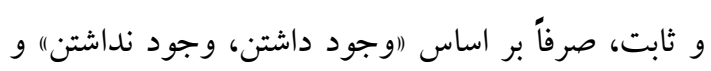

كرديد؛ بنابراين، ملاكك (Tn) از محدودة توزيع خطاى

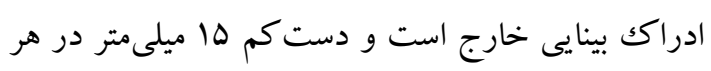
أ. Tr.

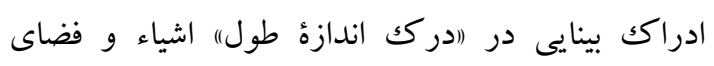

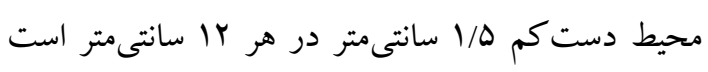

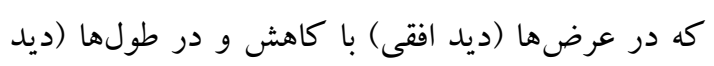

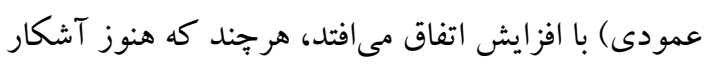

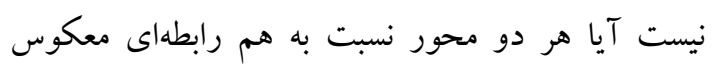
دارند يا اينكه تنها يكى از اين دو تغيير مى كند.

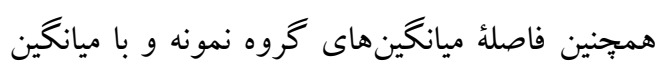

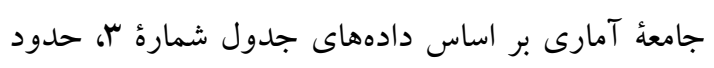

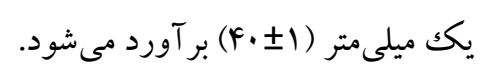

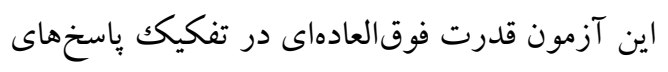

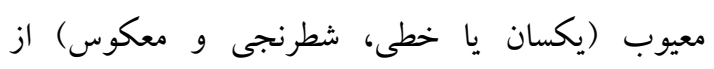

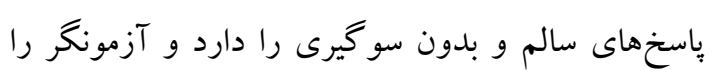

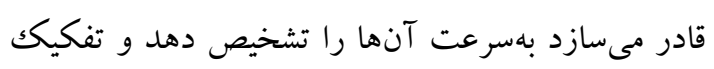

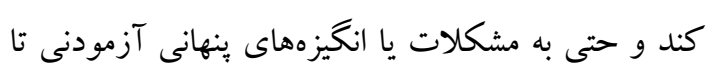

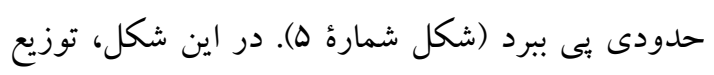

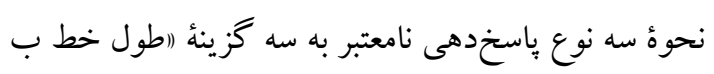

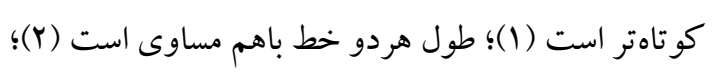

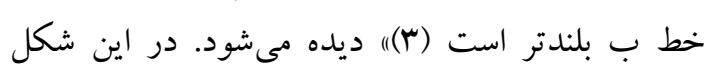

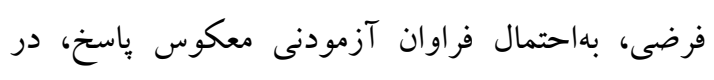

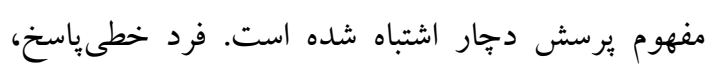




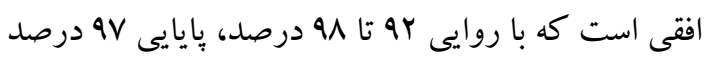

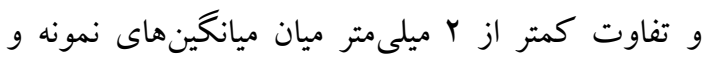
جامعه آمارى، در سطح ه • • قابل تعميم به جامعه است.

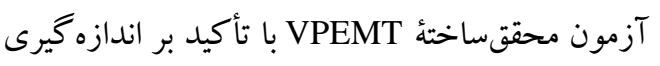

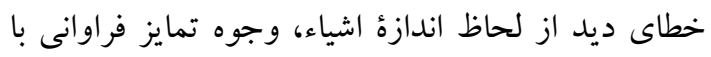

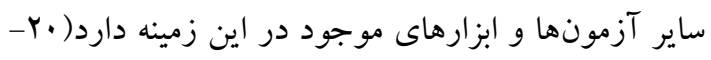

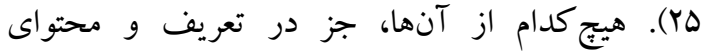
موضوع، از نظر هدف ساختار و روش اجرا مشابهت كاملى با VPEMT ندارند، يا بهعبارتديخر، آزمون آرون

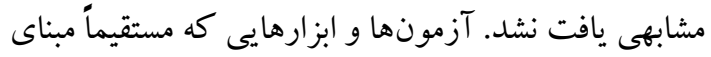

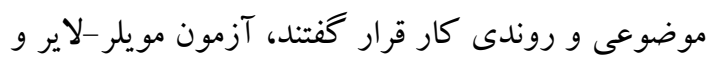
"(سخت-نرم|فزار) سنجش حس دهليزى بودند ، هرجند

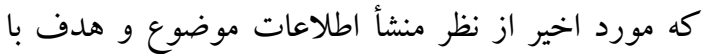

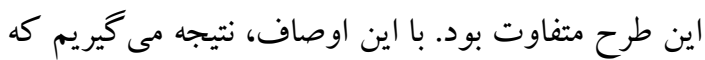

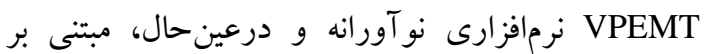
دستاوردهاى بيشين دراينباره است و اهدافى را بر آورده

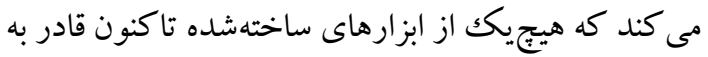
انجام آن نيستد؛ اهداف ارزشمندى كه تحقق آنها زمينه رسيدن به اهداف جديدتر را فراهم مى كند. آزمون

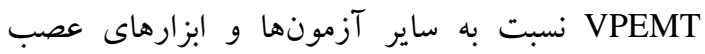

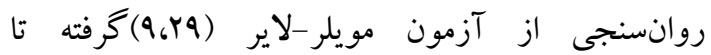

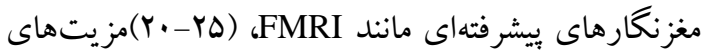

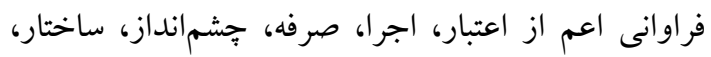

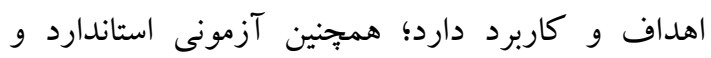

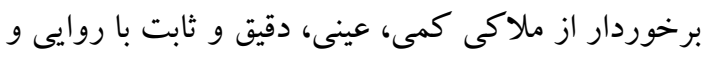

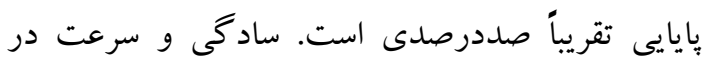

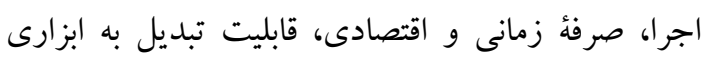

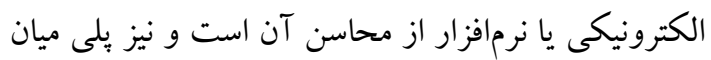

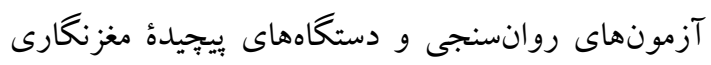
محسوب مىشود كه مىتواند بهعنوان يكك ابزار تحقيقاتى، تشخيصى، ززينشى و... مورداستفادة محققان، متخصصان، درمانگران و متصديان امور گزينش قرينش ورار

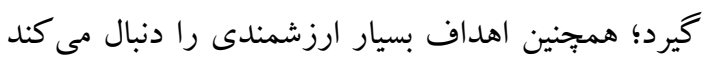

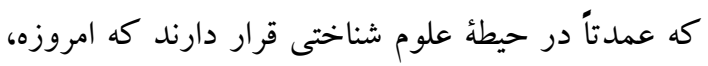

بدون توجه و فهم (جهه مقدار بودن) خطا، براى مقايسٔ

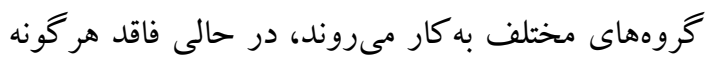

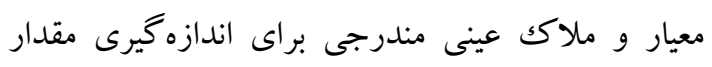

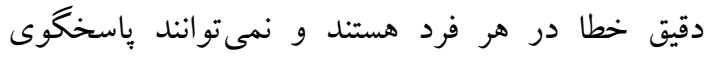
برسشهايى از قبيل (مقدار خطاى ديد يكك فرد نسبت به دهن

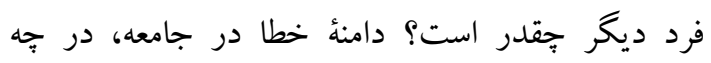
فاصلهاى از ملاكك (مصداق) وجود دارد؟ ميانگين و كرانهاى توزيع خطا در جامعه جقدر است و د در جها

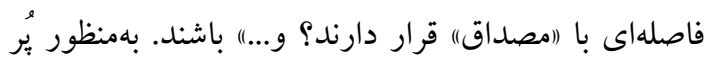
كردن اين خلأ، همسو با تعريف محتوايى و مؤلفهاى

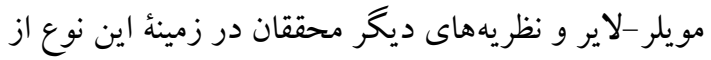

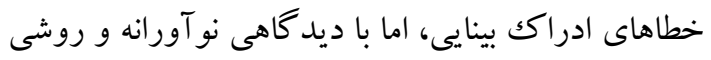

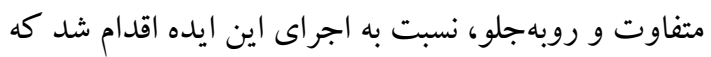
نتيجة آن، توليد وسيلهاى (VPEMT) با ويزكىهاى استاندارد، عينى، جديد، بىنظير و دقيق، قابل ارتقا به ابزارى الكترونيكى، با صرفهُ زمانى و اقتصادى، اجراى

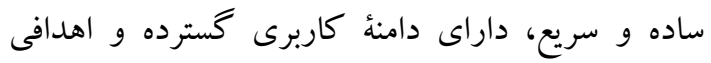
بسيار ارزشمند بود؛ وسيلهاى كه قادر است بر مبناى يك ملاكك كمى (دو بارهخط هماندازهُ .با ميلىمترى/Tn)،

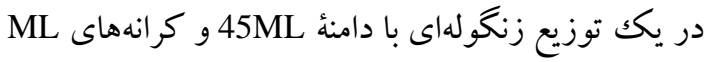
15-60، خطاى ميلىمترى اندازه طول ادراكششده خط يا فضاى ديد عمودى را نسبت به خط يا ديد افقى نشان دهد

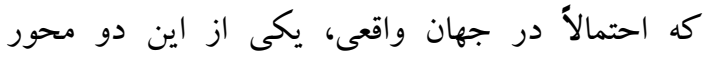

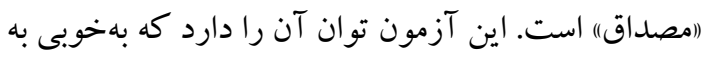
يرسش هاى بالا جواب دهد و جاى خالى خود را در ميان

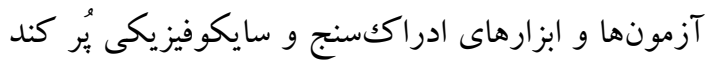

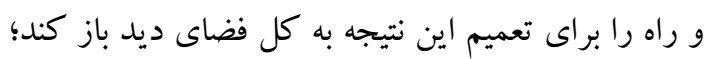

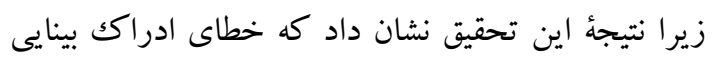

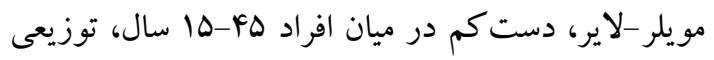

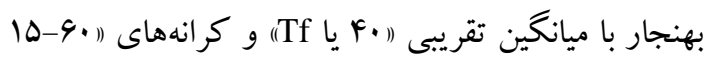
يا Th-Tk) دارد و بيانگر حداقل ها و حداكثر •و ميلىمتر خطا در هر •lY ميلىمتر است؛ يعنى كمترين و بيشترين

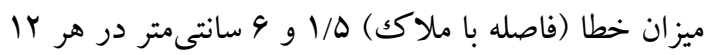
سانتىمتر در تخمين اندازهٔ طول خط عمود نسبت به خط 
يزووهش حاضر، در عين تأييد ويز گیىهاى روانسنجى

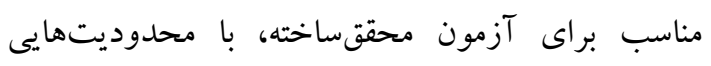

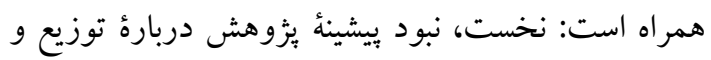

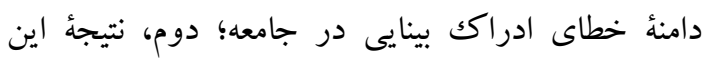
يثروش محدود به افراد D\&-1D سال شهر ايلام است؛ سوم، يايايى و اعتبار آن نيازمند تكرار است. بر اساس اين،

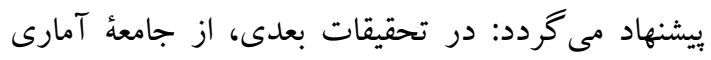

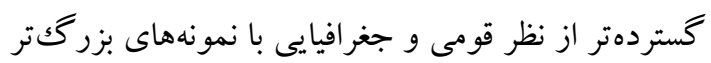
(يوششدهندة همة سنين) و به طريق طولى بهره گرفته

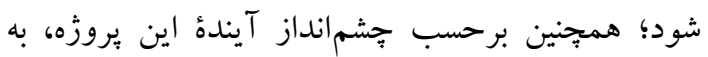

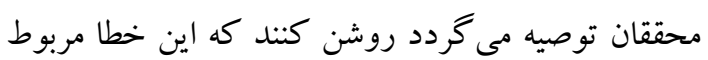

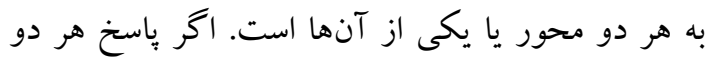
است، تكليف (مصداق) را روشن كنند و اخر يكى است،

$$
\text { (مصداق) و (مدرو كك)) را تعيين نمايند. }
$$

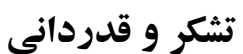

اين مقاله بركرفته از رسالهُ دكتراى تخصصى روانشناسى عمومى است. از استاندارى، دانشخاههاى

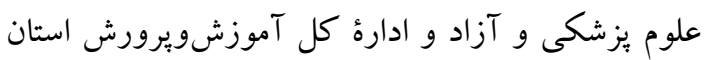
ايلام به سبب صدور مجوز اجراى يُزوهش و همجنين از

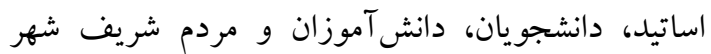
ايلام به دليل همكارى و شركت در آزمون و نيز از اساتيد راهنما جناب دكتر مهدى روزبهانى و جناب دكتر

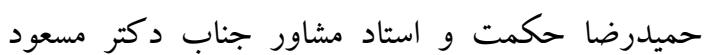
صادقى تشكر و قدردانى مى شود.

\section{كد اخلاق: CER.B.UAI.RI.1398.041}

\section{References}

1. Irvani M, Khodapnahi MK. Psychology of Emotion and Perception, $2^{\text {nd }}$ ed, Tehran Samat Publications. 2018; p. 186-9. (Persian).

2. Pourmazar R. The path of transmission of visual sensory signals to the visual cortex of the brain.2020; Source: Binaei com site. (Persian).

3. Zamora A. Illusions and Paradoxes: Seeing is believing? 2020; Source: scientificpsychic.com site.

4. Kitaoka A \& Tsuinashi S. Visual Illusions and the
بهعنوان قلب علوم نوين و بِ ميان دانش و فناورىهاى هوشمند قلمداد مى گردد(Y) (YD). باين حال، ارجحيت و مناسبت اين آزمون با موضوع و هدف آن كاملاً روشن است. درواقع، راه تازهاى براى بررسى دقيق، آسان و بلدون هزينهاى گزاف فرايند شناختى مغز است كه بر "اباور قابل اندازهگيرى بودن

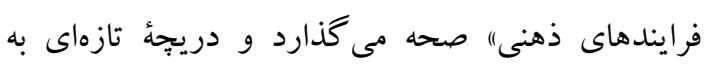
روى تحقيقات مى گشايد. كفتنى است هر جند تاكنون توانستيم اين خطا را از راه مقايسٔ دو محرك در وضعيت متضاد نسبت بههم اندازهگيرى كنيم، نتوانستهايم روشن كنيم كه خطا در يكك يا هر دو محور (عمودى و افقى) رخ مىدهد. اكر در يكك محور رخ مىدهد، آن محور (مدروكك) كدام است تا محور ديگر (امصداق) بهشمار آيد. اخر در هر دو محور با رابطهاى معكوس رخ مىدهد، پس (امصداق)" جه بايد باشد؟ از نظر ئزوهشخر، مشخص شدن (مصداق) كليد اتصال اين دانش به فناورىهاى هوشمند و توانمندساز براى كاهش خطاهاى انسانى خواهد بود. برخلاف اين تصور ظاهرى كه (اخطاى ديد در محور عمودى و بهصورت افزايشى نسبت به محور افقى يا مصداق رخ

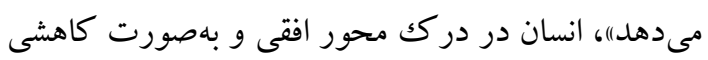
دجار خطاى ديد مىشود كه نتيجه كار كرد شناختى مغز براى متراكم كردن فضاى ديد افقى بهمنظور درك و واكنش سريع به محر كهاى محيطى است كه لازمه بقاى موجود زنده است؛ بنابراين، اين يكك ويز كى است و نه يكك كاستى. هر جند كه اين نظر در حد يك فرضيه است و به تحقيقات بعدى نياز دارد.

Mysteries of Human Perception.2019; Source: ritsumei.ac.jp site.

5. Bumen L. Advanced topics in perception. Bound Psychol 2020; 2:211-29.

6. Shimojo S, Paradiso M, Fujita I. What visual perception tells us about mind and brain? $\mathrm{Na}$ Acad Sci USA 2020; 22:12340-1. doi.10.1073 pnas. 221383698

7. Naceri S (2017). Psychology and its application in education. 1nd.Education Publications 2017, p. 70- 
4. (Persian).

8. Mohammadi Twodasghi MR (2017). The Role of Visual Error in Nahaja Air Accidents in the 1980s and the Strategy for Its Prevention. J Military Sci Tech 2017; 42: 139- 113. (Persian).

9. Zeman A, Obst $\mathrm{O}$ and Brooks KR. Complex cells decrease errors for the Müller-Lyer illusion in a model of the visual ventral stream.J Comput Neurosci 2014: 8: 1-9. Doi: 10.3389/fncom .2014 .00112 .

10. Bays M. Geometric Stability Theory (Munster Model Theory). 2021; version f5f9f04f.

11. Beck DM, Prinzmetal W \& Burke D. The tiltconstancy theory of visual illusions. Journal of Experimental Psychology: Human Perception and Performance.NCBI 2001; 27: 206-217. DOI: 10.1068.

12. Kopiske KK, Bruno N, Hesse C, Schenk T, Franz $\mathrm{VH}$. The functional subdivision of the visual brain: Is there a real illusion effect on action? A multi-lab replication study.J Cortex 2016; 79:130-152. DOI: 10.1016/j.cortex.2016.03.020

13. Malla C, Brenner E, Edward HF, Haan E, Smeets JB. A visual illusion that influences perception and action through the dorsal pathway. J Commun Biol2019; 2:38-45. doi.10.1038/s42003-019-0293

14. Beltramo R, Scanziani M. A collicular visual cortex neocortical space for an ancient midbrain visual structure. J Scie 2019;6422: 64-9. doi.10.1126/science.aau7052.

15. 15. Lewis O, Harvey JR. Detection theory sensory and decision processes. Psychol Perce Psycol2021; 1-16.

16. Ayers M. Oxford University Press; knowing and seeing: Groundwork for a new Empiricism. (ch. 1 co-authored with Maria Rosa Antognazza).Oxford University Press. 2019; p.102-8

17. Briscoe R. Actoin-based theories of perception.Stanford Encyclopedia of Philosophy 2015; Source:plato.stanford.edu/entries/actionperception.

18. Zavagno D, Daneyko $\mathrm{O}$ and Actis-Grosso R. Mishaps, errors, and cognitive experiences: on the conceptualization of perceptual illusions. J Front. Hum. Neurosci 2015; 9:190. Doi: 10.3389 /fnhum.2015.00190.

19. Christensen IP, Wagner HL \& Halliday MS. Instand Notes psychology. 2001; $1^{\text {nd }}$ ed.eBook Published 26 Nov 2020; Pub. Location London. p 56-62. doi.org/10.1201/9781003059332.

20. Amiri SH, Shadmehr A, Ashnagar Z, Jalaei SH. Design and construction of reaction time test system and forecasting skills estimation. J Modern Rehabilitation Faculty of Rehabilitation Tehran University of Medical Sci 2012; 2:26-37. (Persian).

21. Miller K and Schier M. HET426 Instrumentation Project - The Flicker Fusion Frequency Tester. 2007(up 2014); p.11. DOI: 10.13140/ 2.1. 2739.3607.

22. Neurological Laboratory (Humanities) Institute of Higher Education of Cognitive Sciences. Quoted from the site of the Institute of Cognitive Sciences Education. 2020; (Persian).

23. Nematikia M, Gholami A. Design construction and reliability of atrial sensing device. Mot Behav2014; 14: 33-46.APA. new technologies shed light on the brain's form and function.2014;
Source: APA.org.

24. Graybeal J. New technologies shed light on the brains form and function. 2th ed. APA Publication.2014;23-39. 2014;

25. Panahi R. [The brain is a hotbed of new ideas brain and cognition quarterly]. Cogn Sci Technol Dev Head 2020;9: 6-9. (Persian)

26. Ahmadi KH, Javid N (2020). Applications of Cognitive Sciences in Military Sciences - Case Study. J Military Medicine 2020; 1: 12-26. (Persian)

27. . Furnham A. 50 Psychology ideas you really need to know series.9 th ed. Greenfinch UK Publication. 2009; P. 112-24.

28. Alipour A, Mardani Valandani Z, Sadeghi Z. Comparison of Müller Lair perceptual error in students according to their superiority, 4th International Conference on Psychology and Social Sciences, Tehran.2March 2015; (Persian).

29. Millar S \& Al-Attar Z. The Müller-Lyer illusion in touch and vision: implications for multisensory processes. J AP\&P 2002; 3: 353-365.

30. Raja'i M, Safavi SH, Movahedi AR(2020). The effect of Abinghaus visual acuity training (Large Goal Perception-Small Goal Perception) on the performance of targeting skills in contextindependent and context-dependent individuals J.Motor Behavior 2020; 39: 33-50. (Persian). 